\title{
UPAYA KEPALA SEKOLAH SEBAGAI INOVATOR DALAM MENINGKATKAN KINERJANYA DI SD TARBIYATUL ATHFAL
}

\author{
Lailatu Zahroh \\ (Dosen STAI Taruna Surabaya)
}

\begin{abstract}
Abstrak
Penelitian ini bertujuan untuk menjawab beberapa permasalahan yang berkaitan dengan upaya kepala sekolah sebagai inovator dalam meningkatkan kinerjanya, yaitu: (1) Bagaimana upaya kepala sekolah sebagai inovator dalam meningkatkan kinerjanya di SD Tarbiyatul Athfal Surabaya?, (2) Apa faktor pendukung upaya kepala sekolah sebagai inovator meningkatkan kinerjanya di SD Tarbiyatul Athfal Surabaya?, (3) Apa faktor penghambat upaya kepala sekolah sebagai inovator meningkatkan kinerjanya di SD Tarbiyatul Athfal Surabaya?

Permasalahan diatas dijawab melalui kajian penelitian lapangan dengan pendekatan kualitatif dan metode pengumpulan data: obeservasi, wawancara dan dokumentasi.

Hasil penelitian menunjukkan: 1. Upaya kepala sekolah sebagai inovator dalam meningkatkan kinerjanya di Sekolah Dasar Tarbiyatul Athfal Surabaya, yaitu: a. Mengikutsertakan para pendidik dalam penataran-penataran, b. Memberikan kesempatan kepada pendidik untuk meningkatkan pengetahuan dan keterampilannya dengan belajar ke jenjang pendidikan yang lebih tinggi, c. Berusaha menggerakkan tim evaluasi hasil belajar, d. Menggunakan waktu belajar secara efektif di sekolah, e. Membimbing dan mengembangkan pendidik, f. Membimbing tenaga kependidikan, g. Membimbing peserta didik, h. Mengikuti perkembangan ilmu pengetahuan, tehnologi dan seni, dan i. Memberi contoh model pembelajaran dan bimbingan konseling yang baik; 2. Faktor pendukung upaya kepala sekolah sebagai inovator dalam meningkatkan kinerjanya di Sekolah Dasar Tarbiyatul Athfal Surabaya, yaitu: a. Kepala sekolah yang profesional, b. Motivasi pendidik tinggi, c. Motivasi belajar peserta didik tinggi; 3. Faktor penghambat upaya kepala sekolah sebagai inovator dalam meningkatkan kinerjanya di Sekolah Dasar Tarbiyatul Athfal Surabaya, yaitu: a. Sarana prasarana kurang memadai, b. Metode mengajar yang kurang variatif, c. Lingkungan kelas untuk pembelajaran model PAKEM belum maksimal.
\end{abstract}

Kata Kunci: Kepala Sekolah, Inovator, dan Kinerja SDM SD Tarbiyatul Athfal 


\section{A. Pendahuluan}

Sekolah sebagai sistem terbuka, sistem sosial dan agen perubahan, bukan hanya harus peka menyesuaikan diri dengan perkembangan iptek, melainkan seharusnya pula dapat mengantisipasikan perkembangan-perkembangan yang akan terjadi dalam kurun waktu tertentu. ${ }^{1}$ Oleh karena itu, untuk menunjang keberhasilan dalam perubahan-perubahan yang dilakukan perlu dipersiapkan kepala sekolah professional, yang mau dan mampu melakukan perencanaan, pelaksanaan, serta evaluasi terhadap berbagai kebijakan dan perubahan yang dilakukan secara efektif dan efisien.

Kepala sekolah merupakan salah komponen pendidikan yang paling berperan dalam meningkatkan kualitas pendidikan. Erat hubungannya antara mutu kepala sekolah dengan berbagai aspek kehidupan sekolah seperti disiplin sekolah, iklim budaya sekolah dan menurunnya perilaku nakal siswa. ${ }^{2}$ Dalam pada itu, kepala sekolah bertanggung jawab atas manajemen pendidikan secara mikro, yang secara langsung berkaitan dengan proses pembelajaran di sekolah. Sebagaimana dikemukakan dalam Pasal 12 ayat 1 PP 28 Tahun 1990 bahwa: "Kepala sekolah bertanggung jawab atas penyelenggaraan kegiatan pendidikan, administrasi sekolah, pembinaan tenaga kependidikan lainnya, dan pendayagunaan serta pemeliharaan sarana dan prasarana."

Ungkapan diatas sejalan dengan semakin kompleksnya tuntutan tugas kepala sekolah yang menghendaki dukungan kinerja yang semakin efektif dan efisien. Disamping itu, perkembangan ilmu pengetahuan, teknologi, seni dan budaya yang diterapkan dalam pendidikan di sekolah juga cenderung bergerak maju semakin pesat, sehingga menuntut penguasaan secara professional. Keberhasilan sekolah adalah keberhasilan kepala sekolah . ${ }^{3}$

Dalam paradigma baru manajemen pendidikan, kepala sekolah sedikitnya harus mampu berperan sebagai edukator, manajer,

\footnotetext{
Wahyusumidjo, Kepemimpinan Kepala Sekolah Tinjauan Teoritik dan Permasalahannya (Jakarta: Rajagrafindo Persada, 2010), vii.

${ }^{2}$ Supriadi, Reformasi Pendidikan dalam Konteks Otonomi Daerah (Yogyakarta: Adi Cita, 1998), 346

${ }^{3}$ E.Mulyasa, Menjadi Kepala Sekolah Profesional, (Bandung: Remaja Rosdakarya, 2005), 151
} 
administrator, supervisor, leader, inovator, dan motivator (EMASLIM) ${ }^{4}$. Dalam rangka melakukan peran dan fungsinya sebagai inovator, kepala sekolah harus memiliki strategi yang tepat untuk menjalin hubungan yang harmonis dengan lingkungan, mencari gagasan baru, mengintegrasikan setiap kegiatan, memberikan teladan kepada seluruh pendidik dan tenaga kependidikan di sekolah dan mengembangkan model-model pembelajaran yang inovatif.

Melihat adanya perkembangan Sekolah Dasar Islam Tarbiyatul Athfal Surabaya sebagai sekolah dasar yang bercirikan Islam yang begitu cepat memperoleh kepercayaan dari masyarakat dan banyaknya prestasi baik akademik maupun non akademik yang diraih sekolah tersebut di lingkungan Kecamatan Rungkut maupun Kotamadya Surabaya dan malahan sempat di lingkungan Provinsi Jawa Timur, maka penulis tertarik untuk mengangkatnya dalam kajian berjudul "Upaya Kepala Sekolah sebagai Inovator dalam Meningkatkan Kinerjanya di SD Tarbiyatul Athfal Surabaya"

\section{B. Rumusan Masalah}

1. Bagaimanakah upaya kepala sekolah sebagai inovator dalam meningkatkan kinerjanya di SD Tarbiyatul Athfal Surabaya?

2. Apa faktor pendukung upaya kepala sekolah sebagai inovator meningkatkan kinerjanya di SD Tarbiyatul Athfal Surabaya?

3. Apa faktor penghambat upaya kepala sekolah sebagai inovator meningkatkan kinerjanya di SD Tarbiyatul Athfal Surabaya?

\section{Metode Penelitian}

Penelitian ini adalah penelitian kualitatif. Disebut penelitian kualitatif, karena penelitian menggunakan kata-kata atau menuturkan penelitian dari lapangan dalam bahasa dan uraian. ${ }^{5}$ Metode ini menyajikan secara langsung hakikat hubungan antara peneliti dan informan, metode ini lebih peka dan lebih dapat menyesuaikan diri dengan banyak penajaman pengaruh bersama terhadap pola-pola nilai

\footnotetext{
${ }^{4}$ E.Mulyasa, Menjadi Kepala Sekolah Profesional, 98

${ }^{5}$ Sanapiah Faisal, Penelitian Kualitatif (Malang: YA2, 1990), 90 
yang dihadapi, ${ }^{6}$ dan memiliki ciri mengumpulkan data yang banyak tentang percakapan dan prilaku orang dan tempat tertentu, yang tidak mudah diungkapkan dengan menggunakan angka-angka. ${ }^{7}$

Peneliti menggunakan tiga teknik pengumpulan data, yaitu wawancara, observasi dan dokumentasi. Metode wawancara ialah metode pengumpulan data untuk mendapatkan informasi dengan cara bertanya langsung kepada responden. Adapun tujuan wawancara ialah untuk memperoleh konstruksi tentang orang, kejadian, aktifitas, organisasi, perasaan, motivasi serta pengetahuan seseorang. ${ }^{8}$ Metode observasi ialah pengamatan melalui kegiatan pemusatan perhatian terhadap suatu objek dengan menggunakan seluruh alat indera. ${ }^{9}$ Metode dokumentasi ialah metode penelitian untuk memperoleh keterangan dengan cara memeriksa catatan, laporan dan catatan yang dimiliki objek penelitian. Jadi studi dokumentasi digunakan untuk mengumpulkan data dari sumber non manusia yang dapat memberi informasi berupa dokumen. ${ }^{10}$

Data yang terkumpul dianalisis dengan pendekatan kualitatif. Analisis data merupakan proses pencarian dan pengaturan secara sistematis hasil observasi, transkrip wawancara, catatan lapangan dan tambahan lain yang telah dihimpun untuk meningkatkan pemahaman peneliti tentang kasus yang diteliti, yang dilanjutkan untuk pencarian data untuk dilaporkan. ${ }^{11}$ Prosedur dalam analisis data yang disarankan oleh Miles dan Huberman adalah: reduksi data, display data, kesimpulan sementara dan verifikasi. ${ }^{12}$

\footnotetext{
${ }^{6}$ Moleong, Metodologi Penelitian Kualitatif, (Bandung: PT Remaja Rosda Karya, 2000), 5

7 Bogdan \& Biklen, Riset Kualitatif untuk Pendidikan: Pengantar ke Teori dan Metode, Terjemahan Munandir (Jakarta: Dirjen Dikti, 1990), 3

${ }^{8}$ Sonhaji dalam Arifin, Penelitian Kualitatif dalam Bidang Ilmu-ilmu Sosial dan Keagamaan (Malang: Kalimashada Press, 1994).

9 Suharsimi Arikunto, Prosedur Penelitian Suatu Pendekatan Praktek (Jakarta: Rineka Cipta, 1998), 126

10 Winarno Surahmad, Dasar dan Tehnik Research dengan Metodologi Ilmiah (Bandung: Transito, 1989), 162

11 Noeng Muhadjir, Metodologi Penelitian Kualitatif (Yogyakarta: Rake Sarasin, 2000), 36

12 Miles \& Huberman, Qualitative Data Analysis (London: SAGE Publication, 1984), 20
} 


\section{Hasil Penelitian dan Pembahasan}

\section{Upaya kepala sekolah sebagai inovator dalam meningkatkan kinerjanya di SD Tarbiyatul Athfal Surabaya}

Untuk meningkatkan kinerjanya, kepala sekolah sebagai innovator melakukan beberapa upaya yaitu: a. Mengikut sertakan para pendidik dalam penataran-penataran, b. Memberikan kesempatan kepada pendidik untuk meningkatkan pengetahuan dan keterampilannya dengan belajar ke jenjang pendidikan yang lebih tinggi, c. Berusaha menggerakkan tim evaluasi hasil belajar, d. Menggunakan waktu belajar secara efektif di sekolah, e. Membimbing dan mengembangkan pendidik, f. Membimbing tenaga kependidikan, g. Membimbing peserta didik, h, Mengikuti perkembangan ilmu pengetahuan, tehnologi dan seni, dan i. Memberi contoh model pembelajaran dan bimbingan konseling yang baik.

Komponen-komponen di atas dijelaskan sebagai berikut:

\section{a. Mengikut sertakan para pendidik dalam penataran- penataran}

Untuk meningkatkan kinerjanya, kepala sekolah sebagai innovator mengikut sertakan pendidik melalui seminar dan pelatihan yang didasarkan kebutuhan pendidik untuk menunjang peningkatan sumber daya manusia (SDM pendidik), seminar/pelatihan yang dilakukan oleh pendidik SD Tarbiyatul Athfal Surabaya paling sering dilakukan adalah seminar/pelatihan yang diadakan oleh sekolah dan juga dari Dinas Pendidikan diantaranya pelatihan guru kelas VI untuk meningkatkan nilai Ujian Nasional, pelatihan karya ilmiah dan penelitian ilmiah, pelatihan dan lomba guru inovatif, seleksi guru berprestasi, peningkatan SDM pendidik menuju era globalisasi dan lainnya. Hal ini sesuai dengan yang disampaikan Kepala Sekolah SD Tarbiyatul Athfal Surabaya sebagai berikut:

"Untuk meningkatkan kinerja pendidik di SD Tarbiyatul Athfal Surabaya selalu memberikan kesempatan kepada pendidik untuk mengikuti seminar/pelatihan baik yang diadakan oleh sekolah maupun oleh Dinas Pendidikan 
atau instansi lain yang penting ada manfaat bagi pendidik dan selanjutnya dapat diimbaskan kepada peserta didik. Untuk mengikuti seminar/pelatihan pendidik semuanya dibiayai oleh sekolah" (Wawancara dengan Bapak H.UP.Zaenuddin, Kepala Sekolah tanggal 8 April 2013)

Dalam kesempatan yang lain Bapak H.UP Zaenuddin menambahkan:

"Secara rutin sekolah mengikut sertakan pendidik dalam kegiatan peningkatan kinerja guru melalui KKG di UPTD Kecamatan Rungkut, semua guru terjadwal dua minggu sekali. Adapun bentuk program peningkatan kinerja guru yang pernah diikuti oleh pendidik yaitu: diklat pengembangan kurikulum, strategi pembelajaran, sosialisasi kurikulum KTSP, TOT dan peningkatan mutu pendidikan" (Wawancara dengan Bapak H.UP. Zaenuddin, Kepala Sekolah tanggal 18 April 2013)

Guru merupakan ujung tombak keberhasilan pendidikan dan dianggap sebagai orang yang berperanan penting dalam pencapaian tujuan pendidikan yang merupakan pencerminan mutu pendidikan. Keberadaan guru dalam melaksanakan tugas dan kewajibannya tidak lepas dari pengaruh factor internal maupun factor eksternal yang membawa dampak pada perubahan kualitas kinerja guru. Beberapa factor yang mempengaruhi kualitas kinerja guru adalah: kepribadian dan dedikasi, pengembangan profesi, kemampuan mengajar, komunikasi, hubungan dengan masyarakat, kedisiplinan, kesejahteraan, iklim kerja $^{13}$

b. Memberikan kesempatan kepada pendidik untuk meningkatkan pengetahuan dan keterampilannya dengan belajar ke jenjang pendidikan yang lebih tinggi.

${ }^{13}$ Ondi Saondi, Etika Profesi Keguruan (Bandung: PT Refika Aditama, 2010), 24 
Kepala Sekolah memberikan kesempatan bagi para pendidik yang belum mencapai jenjang sarjana (S-1) untuk mengikuti kuliah di STAI Taruna Surabaya dengan biaya diperoleh dari yayasan, yang pelaksanaannya tidak mengganggu kegiatan pembelajaran karena kuliahnya di waktu malam. Sebagaimana yang disampaikan oleh Kepala Sekolah:

"untuk meningkatkan pengetahuan, pendidik dan tenaga kependidikan yang belum S-1 maka dipersilakan kuliah di STAI Taruna Surabaya dengan biaya dari yayasan. Untuk yang ke S-2, harapan ada tapi masih belum" (Wawancara dengan Bapak H.UP.Zaenuddin, Kepala Sekolah tanggal 18 April 2013)

Sehingga pada tahun ajaran 2012/2013 ini semua pendidik yang berjumlah 20 orang baik itu yang berstatus tetap maupun tidak tetap sudah berijazah S-1 semua.

Terminologi pendidik dalam UU Sisdiknas 20/2003 disebut sebagai tenaga pendidikan professional yang memiliki tanggungjawab penuh dalam penyelenggaraan proses belajar mengajar di sekolah/madrasah. Terkait dengan kebijakan pemerintah dalam rangka mengembangkan profesionalisme guru atau profesionalisme tenaga pendidik terkait kualitas tenaga pendidik dijabarkan sebagai berikut:

1) Pendidik harus memiliki kualifikasi minimum dan sertifikasi sesuai dengan jenjang kewenangan mengajar, sehat jasmani dan rohani, serta memiliki kemampuan untuk mewujudkan tujuan pendidikan nasional

2) Pendidik untuk pendidikan formal pada jenjang prndidikan usia dini, pendidikan dasar, pendidikan menengah, dan pendidikan tinggi dihasilkan oleh perguruan tinggi yang terakreditasi

3) Promosi dan penghargaan bagi pendidik dan tenaga kependidikan dilakukan berdasarkan latar belakang pendidikan, pengalaman, kemampuan dan prestasi kerja dalam bidang pendidikan 
4) Sertifikasi pendidikan diselenggarakan oleh perguruan tinggi yang memiliki program pengadaan tenaga kependidikan yang terakreditasi. ${ }^{14}$

\section{c. Berusaha menggerakkan tim evaluasi hasil belajar}

Kepala sekolah berusaha menggerakkan tim evaluasi hasil belajar peserta didik untuk lebih giat bekerja, kemudian hasilnya diumumkan secara terbuka dan diperlihatkan di papan pengumuman. Hal ini bermanfaat untuk memotivasi peserta didik agar lebih giat belajar dan meningkatkan prestasinya. Evaluasi hasil belajar sudah terencana, dan dengan kerja sama dengan guru untuk mengevaluasi setiap KBM, setiap satu indicator ada evaluasi. Adapun bentuknya adalah: ulangan harian, UTS. UAS, Try out kelas VI.

Sebagaimana yang disampaikan oleh Kepala Sekolah:

"Evaluasi hasil belajar sudah terencana sebelumnya, dan saat pelaksanaan dengan kerjasama antara kepala sekolah dengan guru, dan guru dengan guru maka rencana untuk mengevaluasi setiap satu indicator dapat terlaksana. Jenis evaluasi yang ada yaitu ulangan harian, UTS, UAS, Try Out kelas VI" (Wawancara dengan Kepala Sekolah, 25 April 2013)

Adapun dalam pelaksanaan menggerakkan tim evaluasi itu ada faktor pendukung dan penghambatnya, sebagaimana yang disampaikan oleh Kepala Sekolah:

"Faktor pendukung pelaksanaan kebijakan kepala sekolah untuk menggerakkan tim evaluasi hasil belajar yaitu adanya kerjasama semua guru dan yayasan dan perjuangan tinggi dari para guru terhadap keberhasilan evaluasi tersebut. Sedangkan penghambatnya adalah ada sebagian guru yang tidak memahami tupoksi kinerjanya sendiri" (Wawancara dengan Kepala Sekolah, 1 Mei 2013).

${ }^{14}$ LPTK, Fakultas Tarbiyah IAIN Sunan Ampel: 4 
Dengan upaya yang dilakukan kepala sekolah tersebut, prestasi yang diraih oleh peserta didik SD Tarbiyatul Athfal Surabaya sangat membanggakan, baik itu prestasi akademik maupun prestasi non akademik.

Supervisi dan evaluasi proses pembelajaran di SD Tarbiyatul Athfal Surabaya dilaksanakan secara berkala dan berkelanjutan dengan indikator: (a) Supervisi dan evaluasi proses pembelajaran di SD Tarbiyatul Athfal Surabaya dilakukan pada setiap tahap meliputi perencanaan, pelaksanaan dan penilaian (evaluasi) hasil pembelajaran, dan (b) Supervisi dan evaluasi proses pembelajaran dilakukan secara berkala dan berkelanjutan oleh Kepala Sekolah.

Saat wawancara dengan Kepala Sekolah tentang supervisi, beliau menjawab:

"Kegiatan supervisi di sekolah kami belum menyeluruh untuk semua guru dan dititikberatkan pada guru yang telah mengikuti program sertifikasi" (Hasil wawancara dengan Kepala Sekolah, 11 April 2013).

SD Tarbiyatul Athfal Surabaya melaksanakan perencanaan supervisi pembelajaran pada semester 1 dan 2 dengan melibatkan kepala sekolah dan guru senior. Pelaksanaan supervisi antara lain dengan memberikan contoh, diskusi dan pelatihan antara pendidik, kepala sekolah dan guru senior. Hasil supervisi disampaikan kepada pendidik secara mandiri dan secara umum

\section{d. Menggunakan waktu belajar secara efektif di sekolah}

Kepala sekolah SD Tarbiyatul Athfal Surabaya mendorong para guru untuk memulai dan mengakhiri pembelajaran sesuai waktu yang telah ditentukan, serta memanfaatkannya secara efektif dan efisien untuk kepentingan pembelajaran. Ini disampaikan melalui forum rapat guru.Untuk itu setiap saat kepala sekolah melakukan pendekatan responsive terhadap semua guru.

Setiap pendidik memiliki karakeristik khusus, yang berbeda satu sama lain, sehingga memerlukan perhatian dan 
pelayanan khusus pula dari pemimpinnya, agar mereka dapat memanfaatkan waktu untuk meningkatkan kinerjanya. Perbedaan pendidik tidak hanya dalam bentuk fisik, tetapi dalam kondisi psikisnya, misalnya dorongan (motivasi). Oleh karena itu untuk meningkatkan kinerja pendidik, kepala sekolah harus memperhatikan dorongan (motivasi) pendidik dan factor-faktor yang berpengaruh.

Terdapat beberapa prinsip yang dapat diterapkan kepala sekolah untuk mendorong pendidik agar mau dan mampu meningkatkan kualitas kinerjanya. Prinsip-prinsip tersebut menurut E.Mulyasa ${ }^{15}$ sebagai berikut:

1) Pendidik akan bekerja lebih giat apabila kegiatan yang dilakukannya menarik dan menyenangkan

2) Tujuan kegiatan perlu disusun dengan jelas dan diinformasikan kepada para pendidik sehingga mereka mengetahui tujuan dia bekerja. Pendidik juga dilibatkan dalam penyusunan tujuant tersebut.

3) Pendidik harus selalu diberitahu tentang hasil dari setiap pekerjaannya

\section{e. Membimbing dan Mengembangkan Pendidik}

Kepala sekolah berupaya membimbing pendidik, terutama dalam hal-hal yang berkaitan dengan: (1) perencanaan dan pelaksanaan program pembelajaran dan bimbingan konseling (BK), (2) penilaian hasil belajar peserta didik dan layanan bimbingan konseling, (3) analisis hasil penilaian belajar, (4) layanan bimbingan konseling, serta (5) pengembangan program melalui kegiatan pengayaan dan perbaikan pembelajaran (remedial teaching).

Kepala sekolah juga berupaya mengembangkan pendidik, terutama berkaitan dengan: (1) pemberian kesempatan kepada pendidik untuk mengikuti berbagai pendidikan dan latihan secara

${ }^{15}$ E. Mulyasa, Menjadi Kepala Sekolah Profesional dalam Konteks Menyukseskan $M B S$ dan KBK, (Bandung: Remaja Rosdakary, 2005), 121 
teratur, (2) revitalisasi Kelompok Kerja Guru (KKG), (3)diskusi, (4) seminar, (5)lokakarya dan (6) penyediaan sumber belajar.

Kebutuhan yang paling mendalam dari masing-masing orang adalah harga diri, merasa dianggap penting, bernilai dan bermanfaat. Apapun yang kita lakukan dalam interaksi dengan mereka, pasti akan mempengeruhi harga dirinya. Kita harus mempunyai kerangka acuan yang sangat tepat untuk menentukan segala sesuatu yang dapat dilakukan untuk mendorong harga diri mereka, dan karenanya juga memunculkan perasaan kekuatan pribadi mereka.

Tiga hal yang dapat dilakukan setiap hari untuk memberdayakan staf dan membuat mereka merasa nyaman dengan dirinya sendiri adalah yaitu: apresiasi, pendekatan dan perhatian. ${ }^{16}$ Memberdayakan staf merupakan upaya agar dapat lebih optimal dalam bekerja sama. Hal ini juga berhubungan dengan menghargai kemampuan tenaga kependidikan. Kemampuan memberdayakan staf, terutama berkaitan dengan pemberian kesempatan kepada tenaga kependidikan untuk mengikuti berbagai pendidikan dan pelatihan secara teratur: revitalisasi Musyawarah Guru Mata Pelajaran (MGMP), Musyawarah Guru Pembimbing (MGP), dan Kelompok Kerja Guru (KKG), diskusi, seminar, lokakarya, dan penyediaan sumber belajar. Dalam rangka memberdayakan staf, kepala sekolah/madrasah juga harus memperhatikan kenaikan pangkat dan jabatannya.

\section{f. Membimbing tenaga kependidikan}

Disamping membimbing pendidik, kepala sekolah SD Tarbiyatul Athfal Surabaya juga membimbing tenaga kependidikan non guru dalam penyusunan program kerja dan pelaksanaan tugas sehari-hari, serta mengadakan penilaian dan pengendalian terhadap kinerjanya secara periodic dan bekesinambungan. Penilaian dan pengendalian kinerja secara

\footnotetext{
${ }^{16}$ E. Mulyasa, Menjadi Kepala Sekolah Profesional dalam Konteks Menyukseskan $M B S$ dan $K B K, 21$

Jurnal Pendidikan Agama Islam

Volume 02 Nomor 02 November 2013

Hal 256 - 266
} 
periodik dan bekesinambungan penting dilakukan untuk mencapai peningkatan kualitas kerja secara kontinyu.

Dalam membimbing tenaga kependidikan disekolah, konsep Castetter dalam pengembangan sumber daya manusia (PSDM), dapat dijadikan bahan pembanding dalam pengembangannya. Konsep tersebut telah memberikan gambaran yang jelas mengenai pengembangan sumber daya manusia, mulai dari perencanaan, pelaksanaan, sampai dengan evaluasi dan tindak lanjut.

Secara operasional, penerapan konsep Castetter dalam pengembangan tenaga kependidikan di Indonesia dapat diidentifikasikan ke dalam strategi umum dan strategi khusus ${ }^{17}$

a. Strategi Umum

1) Pengembangan tenaga kependidikan harus dilakukan berdasarkan rencana kebutuhan yang jelas. Dengan demikian, tidak akan terjadi ketimpangan antara kebutuhan akan tenaga kependidikan dengan tenaga kependidikan yang tersedia

2) Dalam dunia pendidikan perlu senantiasa dikembangkan sikap dan kemampuan professional. Seorang tenaga kependidikan harus mampu untuk tidak bergantung pada pekerjaan yang diberikan oleh orang lain. Untuk kepentingan tersebut, perlu dikembangkan bukan saja pengetahuan dan kewirausahaan,akan tetapi juga sikap, inisiatif dan kepercayaan atas kemampuan sendiri

3) Kerjasama dunia pendidikan dengan perusahaan perlu terus menerus dikembangkan, terutama dalam memanfaatkan perusahaan untuk laboratorium praktek dan obyek studi.

b. Strategi Khusus

Strategi khusus adalah strategi yang langsung berkaitan dengan pengembangan dan peningkatan

${ }^{17}$ E. Mulyasa, Menjadi Kepala Sekolah Profesional dalam Konteks Menyukseskan MBS dan KBK. 128 
pengelolaan tenaga kependidikan yang lebih efektif. Strategi tersebut berkaitan dengan kesejahteraan, pendidikan prajabatan, rekrutmen dan penempatan, pembinaan mutu pendidik dan pengembangan karier.

Dalam kaitannya dengan kesejahteraaan perlu diupayakan hal-hal sebagai berikut: 1) gaji pendidik perlu senantiasa disesuaikan agar mencapai standar yang wajar bagi kehidupan tenaga kependidikan dan keluarganya, 2) peningkatan kesejahteraan tenaga kependidikan yang didlakukan oleh pemerintah pusat harus diikuti oleh pemerintah daeah, masyarakat, dunia usaha dan orang tua sejalan dengan otonomi daerah yang sedang bergulir, 3) untuk memenuhi kebutuhan pendidik di daerah terpencil perlu diberlakukan system kontrak, dengn system imbalan yang labih baik dan menarik.

\section{g. Membimbing peserta didik}

Membimbing peserta didik, terutama berkaitan dengan kegiatan ekstrakurikuler, partisipasi dalam berbagai perlombaan kesenian, olah raga dan perlombaan mata pelajaran. Kemampuan membimbing peserta didik ini menjadi sangat penting bila dikaitkan dengan manajemen peningkatan mutu berbasis sekolah (MPMBS). Dalam MPMBS, kepala sekolah tidak hanya dituntut untuk meningkatkan prestasi akademik, tetapi juga harus mampu meningkatkan prestasi peserta didik dalam kegiatan non akademik, baik di sekolah maupun di masyarakat.

Hasil dari apa yang sudah dilakukan oleh Kepala Sekolah dan juga para pendidik, maka prestasi peserta didik SD Tarbiyatul Athfal Surabaya sangat membahagiakan dan juga sangat membanggakan. Prestasi yang sudah diraih tidak hanya di tingkat kecamatan, tapi juga tingkat kota, propinsi dan bahkan ada yang sampai tingkat nasional.

Kebutuhan utama yang harus dipenuhi oleh kepala sekolah adalah bahwa peserta didik harus dapat belajar secara optimal. Proses belajar harus menjadi perhatian utama kepala sekolah, dan segala fasilitas yang ada harus diarahkan pada kegiatan belajar 
peserta didik, karena melalui proses belajar yang optimal paling tidak peserta didik sudah dapat diberi layanan prima. Layanan prima harus ;diberikan pada peserta didik bukan hanya kepada peserta didik yang normal, tetapi juga perlu diberikan kepada peserta didik yang punya maslah seperti lambat belajar, karena pesert didik seperti itu harus mendapat layanan dan pembelajaran yang agak berbeda.

Layanan peserta didik juga harus diarahkan pada tersedianya sarana dan prasarana yang diperlukan oleh peserta didik, seperti bauku, alat tulis, dan alat-alat olah raga. Layanan lainnya menyangkut kesehatan peserta didik seperti perlunya P3K dengan anggota PMR yang sudah terlatih.

Perhatian pada peserta didik juga termasuk bagaimana memperhatikan motivasi belajar mereka. Peserta didik yang belajarnya masih memerlukan motivasi dibimbing dengan menugaskan guru BP. Untuk MI dan RA, guru bawahannya perlu dibina oleh kepala sekolah agar dapat bertindak sebagai counselor. Bila perlu bisa meminta bantun pihak lain, misalnya perguruan tinggi yang mempunyai layanan bimbingan. Kerja sama dengan perguruan tinggi ini akan bermanfaat untuk mendapat kan bantuan yang tepat, terutama dalam meningkatkan gairah belajar peserta didik ${ }^{18}$

\section{h. Mengikuti perkembangan ilmu pengetahuan, tehnologi dan seni}

Mengikuti perkembangan ilmu pengetahuan, tehnologi dan seni. Kepala sekolah SD Tarbiyatul Athfal Surabaya meningkatkan kualitas dirinya melalui pendidikan dan latihan; pertemuan profesi seperti Musyawarah Kerja Kepala Sekolah (MKKS); mengikuti diskusi, seminar, dan lokakarya dalam profesinya; menganalisis dan mengkaji berbagai bahan bacaan; serta menelusuri perkembangan informasi melalui media elektronika, seperti computer dan internet. Alhamdulillah, di SD

${ }^{18}$ E. Mulyasa. Manajemen \& Kepemimpinan Kepala Sekolah (Jakarta: Bumi Aksara, 2012), 22 
Tarbiyatul Athfal Surabaya sejak tahun 2011 sudah menggunakan wifi yang bisa diakses oleh semua pendidik dan tenaga kependidikan.

i. Memberi contoh model pembelajaran dan bimbingan konseling yang baik

Memberi contoh model pembelajaran dan bimbingan konseling yang baik, dengan mengadakan analisis terhadap materi pelajaran (AMP), program tahunan (PT), program semester (PS), dan program pembelajaran (PP) atau Rencanan pembelajaran serta mengembangkan daftar nilai peserta didik dan program layanan bimbingan konseling.

Sebagaimana yang disampaikan oleh kepala sekolah:

"SD Tarbiyatul Athfal Surabaya, berupaya menerapkan model pembelajaran PAKEM dan 20 strategi model pembelajaran; sementara Team teaching class yang berjalan bersifat spontan" (Wawancara dengan Kepala sekolah, 1 Mei 2013).

Kepala sekolah dituntut untuk memiliki kemampuan memberikan alternative model pembelajaran yang efektif, dengan mendayagunakan berbagai metode dan sumber belajar secara bervariasi, seperti pendayagunaan computer, LCD dan Tape Recorder dalam pembelajaran.

Sebagaimana yang disampaikan oleh kepala sekolah:

"SDI Tarbiyatul Athfal Surabaya, berupaya menerapkan model pembelajaran PAKEM dan 20 strategi model pembelajaran; sementara Team teaching class yang berjalan bersifat spontan" (Wawancara dengan Kepala sekolah, 1 Mei 2013).

Pembelajaran memiliki sifat yang sangat kompleks karena melibatkan aspek pedagogis, psikologis, dan didaktis secara bersamaan. Aspek pedagogis menunjuk pada kenyataan bahwa pembelajaran berlangsung dalam suatu lingkungan pendidikan. Karena itu, guru harus mendampingi peserta didik menuju 
kesuksesan belajr atau penugasan sejumlah kompetensi tertentu. Aspek psikologis menunjuk pada kenyataan bahwa peserta didik pada umumnya memiliki taraf perkembangan yang berbeda, yang menuntut materi yang berbeda pula. Selain itu, aspek psikologis menunjuk pada kenyataan bahwa proses belajar itu sendiri mengandung variasi, seperti belajar keterampilan motorik, belajar konsep, belajar sikap, dan seterusnya ${ }^{19}$ Perbedaan tersebut menuntut pembelajaran yang berbeda, sesuai dengan jenis belajar yang sedang berlangsung. Aspek didaktis menunjuk pada pengaturan belajar peserta didik oleh guru.

Dalam hal ini, guru harus menentukan secara tepat jenis belajar manakah yang paling berperan dalam proses pembelajaran tertentu, dengan mengingat kompetensi dasar yang harus dicapai. Kondisi eksternal yang harus diciptakan oleh guru menunjuk variasi juga dan tidak sama antar ajenis belajar yang satu dengan yang lain, meskipun ada pula kondisi yang satu dengan yang lain, meskipun ada pula kondisi yang paling dominan dalam segala jenis belajar. Untuk kepentingan tersebut, guru harus memiliki pengetahuan yang luas mengenai jenis-jenis belajar, kondisi internal dan eksternal peserta didik, serta menciptakan pembelajaran aktif, kreatif, efektif dan menyenangkan ${ }^{20}$

\section{Faktor pendukung Upaya kepala sekolah sebagai inovator dalam meningkatkan kinerjanya di SD Tarbiyatul Athfal Surabaya}

Faktor pendukung upaya kepala sekolah sebagai innovator dalam meningkatkan kinerjanya di Sekolah Dasar Tarbiyatul Athfal Surabaya diantaranya: kepala sekolah yang profesional, motivasi pendidik tinggi, dan motivasi belajar peserta didik tinggi.

\section{a. Kepala Sekolah Professional}

Dalam paradigma baru manajemen pendidikan kepala sekolah professional akan memberikan dampak positif dan

${ }^{19}$ Gagne, dalam E. Mulyasa, Kurikulum yang Disempurnakan: Pengembangan Standar Kompetensi dan Kompetensi Dasar (Bandung: Remaja Rosdakarya, 2006), 190

${ }^{20}$ E.Mulyasa, Kurikulum yang Disempurnakan:..., 191. 
perubahan yang cukup mendasar dalam pembaruan system pendidikan di sekolah. Dampak tersebut antara lain terhadap efektifitas pendidikan, kepemimpinan sekolah yang kuat, pengelolaan pendidik dan tenaga kependidikan yang efektif, budaya mutu, teamwork yang kompak, cerdas dan dinamis, kemandirian, partisipasi warga sekolah dan masyarakat, keterbukaan (transparansi) manajemen, kemauan untuk berubah (psikologis dan fisik), evaluasi dan perbaikan berkelanjutan, responsive dan antisipatif terhadap kebutuhan.

\section{b. Motivasi Pendidik Tinggi}

Kepala sekolah SD Tarbiyatul Athfal Surabaya mampu memberikan dorongan/motivasi kepada pendidik untuk bekerja maksimal karena menerapkan prinsip-prinsip untuk memotivasi pendidik agar mau dan mampu meningkatkan kinerjanya diantaranya:

1) Pendidik akan bekerja lebih giat apabila kegiatan yang dilakukannya menarik dan menyenangkan

2) Tujuan kegiatan harus disusun dengan jelas dan diinformasikan kepada pendidik dan tenaga kependidikan sehingga mereka mengetahui mengetahui tujuan dia bekerja. Pendidik juga dapat dilibatkan dalam penyusunan tujuan tersebut

3) Pendidik harus selalu diberitahu tentang hasil dari setiap pekerjaannya

4) Pemberian hadiah lebih baik daripada hukuman, namun sewaktu-waktu hukuman juga diperlukan

5) Memanfaatkan sikap-sikap, cita-cita dan rasa ingin tahu pendidik dan tenaga kependidikan

6) Berusaha untuk selalu memperhatikan perbedaan individual pendidik, misalnya perbedaan kemampuan, latar belakang dan sikap mereka terhadap pekerjaannya

7) Berusaha untuk memenuhi kebutuhan pendidik dengan jalan memperhatikan kondisi fisiknya, memberikan rasa aman, menunjukkan bahwa Kepala Sekolah memperhatikan mereka, mengatur pengalaman sedemikian rupa sehingga setiap pendidik 
dan tenaga kependidikan pernah memperoleh kepuasan dan penghargaan

Prinsip-prinsip yang diterapkan Kepala Sekolah SD Tarbiyatul Athfal Surabaya ternyata benar-benar nyata hasilnya, dan pendidik benar-benar termotivasi untuk melaksanakan kewajiban dengan baik. Dan ini perlu digaris bawahi, karena tanpa motivasi tidak ada kegiatan yang nyata.

\section{c. Motivasi Belajar Peserta Didik Tinggi}

Motivasi belajar peserta didik SD Tarbiyatul Athfal Surabaya adalah kunci utama bagi peserta didik untuk mencapai keberhasilan, karena tanpa motivasi mustahil proses belajar dapat berjalan maksimal. Peserta didik akan melakukan aktifitas belajar bila ada dorongan yang kuat yang menggerakkan mereka untuk berbuat.

\section{Faktor Penghambat Upaya Kepala Sekolah sebagai Inovator dalam Meningkatkan Kinerjanya di SD Tarbiyatul Athfal Surabaya}

Faktor penghambat upaya kepala sekolah sebgai innovator dalam meningkatkan kinerjanya di Sekolah Dasar Tarbiyatul Athfal Surabaya, diantaranya: sarana prasarana kurang memadai, metode mengajar yang kurang variatif, dan lingkungan Kelas untuk Pembelajaran PAKEM belum maksimal.

Berikut ini sebagian dari faktor penghambat tersebut:

\section{a. Sarana Prasarana Kurang Memadai}

Sarana pendidikan adalah peralatan dan perlengkapan yang secara langsung dipergunakan dan menunjang proses pendidikan, khususnya proses belajar mengajar seperti gedung, ruang kelas, meja kursi serta alat-alat dan media pengajaran. Adapun prasarana pendidikan adalah fasilitas yang secara tidak langsung menunjang jalannya proses pendidikan atau pengajaran ,seperti halaman, kebun, taman sekolah, jalan menuju sekolah, tetapi jika dimanfaatkan secara langsung untuk proses belajar mengajar seperti taman sekolah untuk pengajaran biologi, halaman sekolah 
sebagai sekaligus lapangan olah raga, komponen tersebut merupakan sarana pendidikan.

\section{b. Metode Mengajar yang Belum Variatif}

Penerapan metode mengajar yang efektif bagi pembelajaran seperti Active Learning, CTL, Quantum Teaching dan Problem Solving sebagaimana yang dicanangkan perlu diupayakan realisasinya secara terus menerus agar pemahaman guru terhadap pembelajaran PAKEM (aktif, kreatif, inovatif dan menyenangkan) yang saat ini sekitar 50\% - 60\% dapat ditingkatkan lagi, hal ini tidak lain untuk menggapai potensi ideal/optimal yang dimilikinya .Pembelajaran ini harus dikembangkan karena metode pembelajaran ini dirancang agar mengaktifkan anak, mengembangkan kreativitas sehingga efektif namun tetap menyenangkan.

\section{c. Lingkungan Kelas untuk Pembelajaran PAKEM Belum Maksimal}

Dari hasil observasi di SD Tarbiyatul Athfal Surabaya dengan memasuki kelas- kelas yang ada dapat dikatakan bahwa masih ada beberapa hal yang harus dipenuhi bila pembelajaran PAKEM ini ingin diterapkan dan memperoleh hasil maksimal. Dalam PAKEM/CTL, pengelolaan siswa lebih bervariasi. Contoh pengelolaan kegiatan siswa diantaranya: 1) Menyusun alternatif pengelolaan tempat duduk, perabotan, alat dan media yang menunjang pengelolaan siswa secara bervariasi, 2) Menyediakan jenis-jenis kegiatan yang cocok untuk masing-masing pemgelolaan belajar siswa secara klasikal, kelompok dan individu.

\section{E. Kesimpulan}

1. Upaya kepala sekolah sebagai innovator dalam meningkatkan kinerjanya di Sekolah Dasar Tarbiyatul Athfal Surabaya, yaitu: a. Mengikut sertakan para pendidik dalam penataran-penataran, $b$. 
Memberikan kesempatan kepada pendidik untuk meningkatkan pengetahuan dan keterampilan dengan belajar ke jenjang pendidikan yang lebih tinggi, c. Berusaha menggerakkan tim evaluasi hasil belajar, d. Menggunakan waktu belajar secara efektif di sekolah, e. Membimbing dan mengembangkan pendidik, f. Membimbing tenaga kependidikan, g. Membimbing peserta didik, h. Mengikuti perkembangan ilmu pengetahuan, tehnologi dan seni, dan i. Memberi contoh model pembelajaran dan bimbingan konseling yang baik.

2. Faktor pendukung upaya kepala sekolah sebagai innovator dalam meningkatkan kinerjanya di Sekolah Dasar Tarbiyatul Athfal Surabaya yaitu: a. Kepala sekolah yang profesional, b. Motivasi pendidik tinggi, c. Motivasi belajar peserta didik tinggi.

3. Faktor penghambat upaya kepala sekolah sebagai innovator dalam meningkatkan kinerjanya di Sekolah Dasar Tarbiyatul Athfal Surabaya, yaitu: a. Sarana prasarana kurang memadai, b. Metode mengajar yang kurang variatif, c. Lingkungan kelas untuk Pembelajaran PAKEM belum maksimal.

\section{DAFTAR PUSTAKA}

Arifin, Penelitian Kualitatif dalam Bidang Ilmu-ilmu Sosial dan Keagamaan (Malang: Kalimashada Press, 1994)

Bogdan \& Biklen, Riset Kualitatif untuk Pendidikan: Pengantar ke Teori dan Metode, Terjemahan Munandir (Jakarta: Dirjen Dikti, 1990)

E.Mulyasa, Menjadi Kepala Sekolah Profesional dalam Konteks Menyukseskan MBS dan KBK (Bandung: Remaja Rosdakarya, 2005)

E. Mulyasa, Kurikulum yang Disempurnakan Pengembangan Standar Kompetensi dan Kompetensi Dasar (Bandung: Remaja Rosdakarya, 2006)

E. Mulyasa, Manajemen \& Kepemimpinan Kepala Sekolah (Jakarta: Bumi Aksara, 2012)

LPTK, Fakultas Tarbiyah IAIN Sunan Ampel, Surabaya

Miles \& Huberman, Qualitative Data Analysis (London: SAGE Publication, 1984) 
Moleong, Metodologi Penelitian Kualitatif (Bandung: PT Remaja Rosda Karya, 2000)

Noeng Muhadjir, Metodologi Penelitian Kualitatif (Yogyakrta: Rake Sarasin, 2000)

Ondi Saondi, Etika Profesi Keguruan (Bandung: PT Refika Aditama, 2010).

Sanapiah Faisal, Penelitian Kualitatif (Malang: YA2, 1990)

Suharsimi Arikunto, Prosedur Penelitian Suatu Pendekatan Praktek (Jakarta: Rineka Cipta, 1998)

Supriadi, Reformasi Pendidikan dalam Konteks Otonomi Daerah (Yogyakarta: Adi Cita, 1998)

UP. Zaenuddin, Kepala Sekolah, Wawancara pada tanggal 8 April, 11 April, 25 April, 1 Mei 2013.

Wahyusumidjo, Kepemimpinan Kepala Sekolah Tinjauan Teoritik dan Permasalahannya (Jakarta: Rajagrafindo Persada, 2010)

Winarno Surahmad, Dasar dan Tehnik Research dengan Metodologi Ilmiah (Bandung: Transito, 1989) 